\title{
NEW DEVELOPMENTS IN
}

\section{SHEEP PRODUCTION}

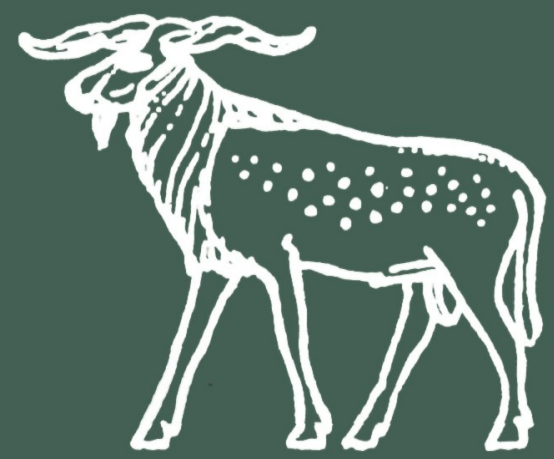

AN OC'ASIONAL, PL BI.IC ATION

(OF THE

BRITISH SOCIETY OF ANIMAL, PROIDL CTION 
The British Society of Animal Production's Occasional Publication Series contains the full papers presented at certain symposia organized by the Society. A full list of titles is given on the back cover of this Publication. Copies may be obtained from the British Society of Animal Production, PO Box No. 3, Penicuik, Midlothian EH26 0RZ, Scotland. 


\section{NEW DEVELOPMENTS IN}

\section{SHEEP PRODUCTION}

Proceedings of a symposium organized by

THE BRITISH SOCIETY OF ANIMAL PRODUCTION

and held in Malvern in October 1989

\section{BSAP OCCASIONAL PUBLICATION \\ Number 14}

edited by C. F. R. SLADE and T. L. J. LAWRENCE

technical editors HILARY DAVIES and MARIE C. PITKETHLY

BSAP

EDINBURGH

1990

Occ. Publ. Br. Soc. Anim. Prod., No. 14 
ISBN 0906562147

(C) 1990 THE BRITISH SOCIETY OF ANIMAL PRODUCTION

Printed in Great Britain by D. \& J. Croal Ltd., Haddington. 


\section{ACKNOWLEDGEMENTS}

The British Society of Animal Production is grateful to the members of the Technical Committee and Secretariat who organized the Conference:

C. F. R. Slade, B. Bastiman, B. R. Hardy and R. G. Gunn.

That the Conference ran smoothly and almost to time is thanks to a number of Chairmen and Discussion Group Leaders who led the proceedings:

M. Bichard, J. F. O’Grady, R. G. Gunn, W. J. M. Black, C. McLean, C. F. R. Slade, J. H. D. Prescott, S. Marsden, J. M. Forbes, D. Croston, T. H. McClelland, R. N. Rutherford and N. Pickard.

A number of practical demonstrations and displays were organized during the Conference and the Society is grateful to the staff of the AFRC Institute of Food Research - Bristol Laboratory and the Meat and Livestock Commission who contributed to this session:

J. D. Wood, A. V. Fisher, J. B. Kilkenny, B. Dean and G. Binks.

The following Companies sponsored the Conference and the Society is most grateful for their help and support:

Dalgety Agriculture Ltd

BOCM Silcock Ltd

BP Nutrition (UK) Ltd

Colborn-Dawes Nutrition Ltd

J. Bibby Agriculture Ltd

Smith Kline Animal Health Ltd. 


\section{LIST OF DELEGATES}

Dr M. Bichard, Hon. President, BSAP, Pig Improvement Company, Oxfordshire.

Aitken, Dr I. D. Ap Dewi, Dr I. Appleton, Mr M. Awulo, Mr P. Baker, Miss D. J. Barber, Mr J.

Barton, Mr J. N. Basiouni, Mr G. Bastiman, Mr B. Bateman, Miss S. Bicer, Dr O. Binks, Mr G. Bird, Mr A. F. Black, Miss H. Black, Dr W. J. M. Blake, Dr J. S. Boundy, Mr T. Bradnock, Mr P. Brown, Mr D. C. Burke, Mr W. Butler, Mrs G. Cahn, Mr A. Cave-Penny, Mr A. L. Chestnutt, Dr D. M. B. Clark, Dr H. Cornwell-Smith, Mr M. J. Crosby, Dr F. Crosby, Mrs T. Croston, Mr D. Curran, Dr M. K. Curtis, Dr R.

Darling, Mrs J. Darroch, Mr R. A. Davies, Mr D. A. R. Davies, Mr M. H. Davis, Miss F. Dingwall, Dr W. S. Doney, Dr J. Edwards, Mr M. Egan, $\mathrm{Mr} \mathrm{T}$. Faithfull, Mr J. R. C. Fisher, Mr A. V.
Moredun Research Institute, Edinburgh.

UCNW, Bangor.

ADAS, Liscombe EHF, Somerset.

Berkshire College of Agriculture.

Hoechst Animal Health, Milton Keynes.

Crogham Farm, Norfolk.

Berkshire College of Agriculture.

University of Nottingham.

ADAS, High Mowthorpe EHF, Yorkshire.

University of Nottingham.

Institute of Food Research, Bristol.

MLC, Milton Keynes.

ADAS, Gloucester.

ARINI, Hillsborough.

BSAP, Hon. Treasurer, Edinburgh.

BOCM Silcock Ltd, Basingstoke.

Veterinary Surgeon, Powys.

New Zealand High Commission, London.

ADAS, Rosemaund EHF, Herefordshire.

IAWS Group Ltd, Dublin.

ADAS, Newcastle.

MAFF, Sheep Policy Division, London.

Press, Hampshire.

ARINI, Hillsborough.

ADAS, Liscombe EHF, Somerset.

ADAS, Bristol.

University College, Dublin.

MLC, Milton Keynes.

Wye College, University of London.

Cambridge Animal and Public Health Ltd, Essex.

BSAP, Edinburgh.

Agricultural Training Board, West Wickham.

University of Liverpool.

ADAS, Rosemaund EHF, Herefordshire.

Wye College, University of London.

Edinburgh School of Agriculture.

Retired, Edinburgh.

ADAS, Penrith.

TEAGASC, Agricultural and Food Development Authority. ADAS, Cumbria.

Institute of Food Research, Bristol. 
Flanagan, Dr S.

Forbes, Prof. J. M.

Foster, Mr C. J.

Fraser, $\mathrm{Mr} \mathrm{D}$.

Frazer, Mr A.

Gill, Dr R. D.

Glatt, Mr R.

Goddard, Mr S.

Graham, Mr M.

Griffiths, Miss M. S.

Gronow, Mr J.

Gunn, Dr R. G.

Haresign, Dr W.

Harker, Mr A. B.

Harvey, Mr. V.

Higginbotham, Dr J. D.

Hill, Dr R.

Hindson, $\mathrm{Mr} \mathrm{J}$. C.

Howard, Mr D. W.

Hughes, Mr G.

Hutchings, Mr L.

Irwin, Mr J. H. D.

Jarrett, Mr D.

Jolley, Mr P. D.

Keatinge, Mr R.

Kelly, Mr P.

Kenyon, Mr P.

Kilkenny, Mr J. B.

King, Miss M.

Kinsella, Dr A.

Kinsella, Mrs B.

Kirk, Dr J.

Kusaybati, Mr M.

Lister, Dr C. J.

MacLean, Dr C.

Main, Mr J.

Margetson, Mr D.

Marsden, Dr M.

Marsden, Dr S.

Marsh, Miss L. R.

Massaquoi, Mr A.

McCalman, Dr H.

McClelland, $\mathrm{Mr}$ T. $\mathrm{H}$.

Merrell, Mr B.

Millington, Mr S.

Mitchell, Dr L.

Morgan, Mr I.

Moser, Mrs R. J.

Mowat, Mr D. L.
TEAGASC, Belclare, Co. Galway.

University of Leeds.

Pinmoor Farm, Moretonhampstead, Devon.

Celtic Feeds, Dyfed.

New Zealand Meat Producers Board, London.

British Technology Group, London.

University of Aberdeen.

Cambridge Animal and Public Health Ltd, Essex.

Wynnstay Farmers, Powys.

ADAS, Trawsgoed.

Lopen Feed Mill Ltd, Somerset.

BSAP, Hon. Secretary, Edinburgh.

University of Nottingham.

BOCM Silcock Ltd, Renfrew.

MLC, Milton Keynes.

. Tate and Lyle Animal Nutrition, Staffordshire.

Royal Veterinary College, Potters Bar.

North Park Veterinary Group, Devon.

ADAS, Trawsgoed EHF, Aberystwyth.

ADAS, Powys.

Abivale Veterinary Group, Oxfordshire.

Department of Agriculture, $\mathrm{N}$ Ireland.

ADAS, Caernarfon.

Institute of Food Research, Bristol.

ADAS, Cambridge.

ADAS, Bristol.

BOCM Silcock Ltd, Basingstoke.

MLC, Milton Keynes.

North of Scotland College of Agriculture, Aberdeen.

TEAGASC, Grange, Co. Meath.

Seale Hayne, Devon.

University of Reading.

Carrs Agriculture, Carlisle.

MLC, Milton Keynes.

Dalgety Agriculture Ltd, Herefordshire.

Coopers Animal Health Ltd, Crewe.

J. Bibby Agriculture Ltd, Oxfordshire.

Dalgety Agriculture Ltd, Bristol.

Wynnstay Farmers, Clwyd.

ADAS, Reading.

Edinburgh School of Agriculture.

ADAS, Redesdale EHF, Northumberland.

Farmer, Stourton, Warminster.

North of Scotland College of Agriculture, Aberdeen.

MLC, Malvern.

ADAS, Taunton. 
Mulroy, Miss C.

Murray, Miss B.

Notman, $\mathrm{Mr}$ A. B.

O'Grady, Dr J. F.

Owen, Mr B.

Packington, $\mathrm{Mr}$ A. J.

Payne, Mr G.

Payne, Dr W. J. A.

Pick, Mr J.

Pickard, Dr D. P.

Pickard, Mr N.

Phillips, Mrs K.

Povey, Miss G. M.

Power, Mr T.

Prescott, Prof. J. H. D

Price, Mr E. J.

Richardson, Dr R. I.

Robinson, Dr J.

Roger, Mr P.

Rogers, Mr C.

Rose, Mr A. R.

Rowland, Dr H.

Rutherford, Mr R. N.

Scully, Mr G.

Shirley, Mr J.

Shomoro, Mr K.

Simpkin, Mr P. G.

Slade, Mr C. F. R.

Smith, Mr K. C.

Steele, Mr M.

Stimpson, Mr P.

Stone, Mr C. R.

Tait, Dr R. M.

Tait, Mrs M.

Thirkell, Mrs E. J.

Thomas, Miss E. M.

Thompson, Dr F.

Thomson, Mr W.

Thorgeirsson, Dr S.

Thornton, Mr D.

Treacher, Dr T. T.

Vipond, Dr J. E.

Walls, Ms M.

Waterhouse, Dr A.

Webster, Dr G. M.

Welham, Mr M.

Williams, Dr H. Ll.

Wood, Dr J. D.
ADAS, Pontypool.

University College, Dublin.

Writtle College, Essex.

IAWS Group Ltd, Dublin.

ICI plc, Macclesfield.

Colborn-Dawes Nutrition Ltd, Heanor.

Harper Adams Agricultural College, Shropshire.

Broadway, Worcestershire.

Press, Big Farm Weekly.

University of Leeds.

ADAS, Leamington Spa.

ADAS, Wolverhampton.

University of Newcastle upon Tyne.

TEAGASC, Co. Wexford.

Wye College, University of London.

Dalgety Agriculture Ltd, Bristol.

Institute of Food Research, Bristol.

Rowett Research Institute.

Veterinary Surgeon, N Yorkshire.

MAFF, London.

Dalgety Agriculture Ltd, Bristol.

Farmer, Brecon, Powys.

ADAS, Northallerton.

TEAGASC, Co. Galway.

Irish Farmers Journal.

Berkshire College of Agriculture.

Dalgety Agriculture Ltd, Preston.

ADAS, Wolverhampton.

Smith and Partners, Veterinary Surgeons, Somerset.

BSAP, Assistant Secretary, Edinburgh.

Underwood and Croxson, Guildford.

ADAS, Liscombe EHF, Somerset.

University of British Columbia.

Royal Veterinary College, Potters Bar.

ADAS, Rosemaund EHF, Herefordshire.

Rumenco, (Tate and Lyle Animal Nutrition Group) Burton-on-

Trent.

Harbro Farm Sales Ltd, Turriff.

Agricultural Research Institute, Iceland.

DAFS, Edinburgh.

IGAP, Hurley.

Edinburgh School of Agriculture.

West of Scotland College of Agriculture, Stirling.

University of Newcastle upon Tyne.

Consultant, Oxfordshire.

Royal Veterinary College, Potters Bar.

Institute of Food Research, Bristol. 


\section{CONTENTS}

CAHn, A. The EC sheep meat regime - the political dimension

Slade, C. F. R. UK sheep industry: current position, economics and emerging trends

Curran, M. K. Practical breeding developments and future prospects

HAREsign, W. Controlling reproduction in sheep ................................... 23

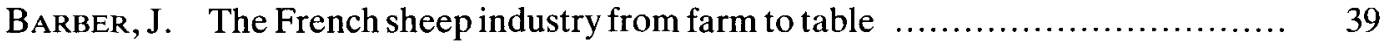

TrEacher, T. T. Grazing management and supplementation for the lowland sheep flock

Robinson, J. J. Nutrition over the winter period - the breeding female

Webster, G. M. and Povey, Gillian M. Nutrition of the finishing lamb

AitKen, I. D. Sheep health: research developments and emerging problems ........ 83

Hindson, J. Sheep health: husbandry and production problems $\ldots \ldots \ldots \ldots \ldots \ldots \ldots \ldots . . . \ldots 3$

Wood, J. D. and Fisher, A. V. Improving the quality of lamb meat - taste, fatness and consumer appeal

KILKENNY, J. B. Changes in quality specifications for different markets ...............

Richardson, R. I., Taylor, A. A. and Jolley, P. D. Added value products from lamb

\section{Abstracts of poster presentations}

Chestnutr, D. M. B. Effect of sward height on the productivity of grass/clover and nitrogen fertilized grass swards continuously grazed by sheep ......................

Howard, D. W., Griffiths, M. S. and JAmEs, C. Clover development and animal production under continuous grazing

Stone, C. Grazing control for ewes and lambs (supplemented at turn-out) using sward height

Vrpond, J. E., Swift, G., McClelland, T. H. and Milne, J. A. Evaluation of a perennial ryegrass and small-leaved clover sward without nitrogen fertilizer under continuous sheep grazing at a controlled sward height

Logue, D. N., Gill, A., MacAuslan, J., Waterhouse, A., Boyd, J. S. and HARveY, M. J. A. The incorporation of the 'Booroola gene' into the Texel breed of sheep

Merrell, B. G. The effect of duration of flushing period and stocking rate on the reproductive performance of Scottish Blackface ewes

Williams, H. Ll., Hanif, M. and Cairns, G. The use of light and melatonin treatments in the preparation of Suffolk rams for out-of-season breeding ..........

Black, H. J. and ChestnutT, D. M. B. Influence of shearing treatment on the performance of pregnant ewes offered silage on an ad libitum or restricted basis ...

King, Margaret E. and Mitchell, Linda M. Comparative performance of Mule ewes bred at 6 or 18 months of age

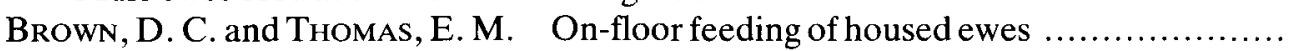

Kossaibati, M. A. and Bryant, M. J. Effects of supplementation upon the

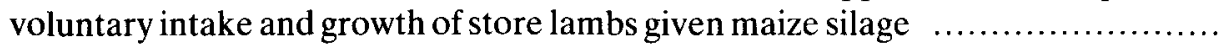

Povey, Gillian M., Webster, G. M. and Weekes, T. E. C. The responses of silage-fed Scottish Blackface lambs to increasing levels of fish meal supplementation with or without additional barley 
Waterhouse, A., Roger, Louise C. and Harker, A. B. The effects of diet, timing of housing and timing of slaughter on the performance of ad libitum concentrate finished Scottish Blackface wether lambs

Simm, G., Dingwall, W. S., Murphy, S. V. and Brown, W. R. Selection for improved carcass composition in terminal sire sheep breeds

Merrell, B. G., Webster, G. M. and Ellis, M. A comparison of three terminal sire breeds for crossbred lamb production. 1. Growth performance and carcass classification

Webster, G. M., Ellis, M. and Merrell, B. G. A comparison of three terminal sire breeds for crossbred lamb production. 2. Carcass evaluation

Ap Dewi, I., Owen, J. B. and Williams, G. Ll. An analysis of ultrasonic fat and muscle measurements in hill ewe and ram lambs

\section{Workshop reports}

Croston, D. The implications of political changes and new techniques for the lowland sector

MCClelland, T. H. Implications of political changes and new techniques for the hills and uplands

Rutherford, R. N. Implications of political changes and new techniques for out-of-season lambing

PICKARD, N. Implications of political changes and new techniques for store lamb finishing

Prescott, J. H. D. Conference summary 